\title{
Determinants of New Small and Medium Enterprises (SMEs) Access to Bank Credit: Case Study in the Phu Tho Province, Vietnam
}

\author{
Hung D. Pham ${ }^{1}$ \\ ${ }^{1}$ Georg-August-Universität Göttingen, Faculty of Economics Sciences, Chair of Economic Policy and SME \\ Research, Germany \\ Correspondence: Hung D. Pham, Georg-August-Universität Göttingen, Faculty of Economics Sciences, Chair of \\ Economic Policy and SME Research, Heinrich-Düker-Weg 6, 37073 Göttingen, Germany. E-mail: \\ phung@wiwi.uni-goettingen.de
}

Received: April 5, 2017

Accepted: May 9, 2017

Online Published: June 7, 2017

doi:10.5539/ijbm.v12n7p83

URL: https://doi.org/10.5539/ijbm.v12n7p83

\begin{abstract}
Small and medium-sized enterprises (SMEs) play a very important role in the Vietnamese economy. Specifically, new SMEs are seen as a suitable solution to cope with development issues such as poverty and a high unemployment rate. In Vietnam, a high SME failure rate is due to lack of capital and poor managerial experience of owners. Most existing research on SMEs focuses on well-established stages, and less attention is paid to new SMEs. This paper investigates the determinants of credit access by SMEs existing for less than forty-two months in the Phu Tho province located in Northern Vietnam. The quantitative data were collected from 259 SMEs in 2015. The regression analysis reveals that a business plan, the firm size, and networking (emotional trust, knowledge trust, and approachability) are the main drivers of access to bank loans by new SMEs. About 64\% (165 observations) of new SMEs in our sample did not get any bank loan caused by high collateral requirements, unfavorable interest rate, poor business plans, limited networking, and lack of the government support. The results also indicate that, among the selected explanatory variables, having a concrete business plan significantly affects the bank loan ratio (total bank loans over total capital). Based on these results, we derived political implications.
\end{abstract}

Keywords: new SMEs, bank loan, business plan, networking, Vietnam

JEL Classification: M13, F65, G20

\section{Introduction}

Small and medium enterprises (SMEs) play a vital role in economic growth worldwide. They substantially contribute to economic growth by creating jobs (Chandler, 2012; Hu \& Schive, 1998; Neumark, Wall, \& Zhang, 2011; Wit \& Kok, 2014), reducing poverty (Beck, Demirguc-Kunt, \& Levine, 2005), and bringing about innovations (Hemert, Nijkamp, \& Masurel, 2013; Lee, Park, Yoon, \& Park, 2010). While large businesses are necessary to preserve and maintain structure within economies, SMEs are often considered as main drivers of economic development (Ayodeji \& Balcioglu, 2010). They account for approximately $95 \%$ of total enterprises in the OECD area (OECD, 2004), involving many business activities in both domestic and international markets.

A World Bank report (2015) states that over 50\% of SMEs worldwide are in short of capital what is considered as a main constraint to their growth. The situation is even worse in many developing countries because of high collateral requirements (Beck, Demirgüç-Kunt, \& Maksimovic, 2005; Malhotra et al., 2007; Vo, T.C. Tran, V. D. Bui, \& D. C. Trinh, 2011), lack of managerial skills and ineffective institutional structures (Beck, Demirgüç-Kunt et al., 2005), limited networking, unfavourable business environment (Ayyagari, Demirgüç-Kunt, \& Maksimovic, 2006), limited access to right certificated land, and high administration costs. Improving access to finance or bank credit could be a key to overcome these obstacles. As a result, governments have implemented several targeted policies to support enterprises, for instance, subsidised credit, reducing tax burdens and providing start-up grants.

Vietnam had succeeded in shifting the planned economy to a market-oriented economy since 1986. The economy (with a population of nearly 92 million) has continued growing at $6 \%$ annually in the last five years. Because of its positive development, Vietnam is an interesting case study for research on SMEs (World Bank, 2015). According to the General Statistics Office (GSO) of Vietnam (2014), the country had 324691 enterprises, $258656(80 \%)$ of 
which were micro enterprises, $14 \%$ were small, and only $4 \%$ were medium size. These SMEs generate approximately $40 \%$ of annual gross domestic product (GDP). In addition, more than half of all employed Vietnamese citizens work in SMEs. Like other developing and transition countries, the Vietnamese government emphasises the importance of SMEs for long-term development. For example, the government has introduced numerous policies such as an economic reform programme (1986), the Company Law and Private Enterprise Law (1990). These laws were amended to the Enterprise Law (2005), the Decree No. 56/2009/ND-CP (2009) in order to support the development of SMEs. Recently, the Decision No.58 (2013) was implemented to set up an SME credit guarantee fund.

However, the growth contribution of SMEs is not likely to be sustained without establishing and supporting new businesses. Failures of SMEs occurred especially after the financial crisis of 2007-2008. In order to offset the failures, new SMEs are required. According to the GSO (2014), there were 76955 enterprises set up in 2013, but also 60737 enterprises failed due to the lack of capital. The majority of Vietnamese SMEs begin the business with capital from internal sources (e.g., borrowing from their families, friends, and relatives). Most of the time, such sources are not sufficient to adequately support the business development. As a result, bank loans could play a very important role as an external funding source for the long-term development of SMEs.

Financial constraints are a major source of business failure in developing countries. However, to our best understanding, previous research has not well analysed the determinants of securing access to financing for new SMEs in developing countries, especially not in Vietnam. We aim to close this research gap by exploring the determinants of access to finance for new SMEs in Northern Vietnam.

We try to understand how new SMEs acquire finance and identify drivers of access to finance. The term "new" SMEs could mean new firms, newly founded firms, or newly created firms, meaning those firms which begin at the business plan stage (Reynolds, 1987; Robb \& Robinson, 2013). In this paper, the term "new" SMEs refers to those enterprises that have existed for less than forty-two months (Luong, Pham, Le, Doan, \& Doan, 2016; Maas \& Herrington, 2007).

For a definition of SMEs, we followed the Vietnamese Decree No. 56 (2009): "SMEs are enterprises have registered capitals less than VND 100 billion (USD 4.5 million) or an average number of annual employees of less than 300."

The rest of the article is organised as follows: Section 2 reviews the literature on access to debt finance of SMEs in developing countries. Section 3 provides the research methodology and develops testable hypotheses. Section 4 shows the regression results. Finally, the article closes with a conclusion and suggests implications to policy-makers and SMEs' owners in developing countries.

\section{Literature Review}

\subsection{SMEs' Financing Problems in Developing Countries}

Bank loans have been considered a crucial element for the growth process of SMEs not only in developed countries but also in developing countries (Nguyen, Le, \& Freeman, 2006; The United Nations, 2001; World Bank, 2015). Compared to larger enterprises, SMEs have less access to finance provided by banks, stock markets or private equity markets (Beck, Demirgüç-Kunt et al., 2005). As major constraints for SMEs in developing countries to access external bank loans, Beck (2007) found high transaction costs and asymmetric information. In addition to these two constraints, the United Nations (2001) pointed out high interest rates and insufficient assets.

Asymmetric information occurs when one business partner cannot provide full information to the contracting party (Le, 2013; Malhotra et al., 2007). Le (2013) illustrates that a borrowing SME itself has more information about the credit risk than the bank providing the credit. SMEs usually know the specific market conditions in the markets they operate in better than banks. They are also more aware of risks within small enterprises such as their productivity, their operational capacity, the condition of the machines and facilities, etc. To solve the problem of asymmetric information, banks or financial institutions have applied common strategies, e.g., collateral requirement, collecting information on SMEs, building networks, and applying strict contracts.

Measures to resolve asymmetric information regularly raise transaction costs, which are the major obstacle for SMEs' access to bank loans. Transaction costs are considered a main constraint for the access of SMEs to credit (Malhotra et al., 2007). The cost is measured by summing up the costs from borrowers and lenders to give their decisions related to the exchange of credit. It is caused by the imperfect information in credit markets (Le, 2013).

The relationship between newly founded firms and banks or financial suppliers generally is very weak. Banks have to search for information from their clients and predict their actions. Transaction costs are higher if banks 
have to hand out many small loans that require more administration work to control risks (Malhotra et al., 2007). SMEs also experience transaction costs if they have to provide information or invest in networks in order to secure credits (Malhotra et al., 2007).

For our paper, the question is crucial whether new SMEs have more constraints to access bank loans than more mature SMEs. The literature on the access of new SMEs to credit is limited. Only few studies explore the situation in developed countries (Reynolds, 1987). For example, Reynolds (1987) found that new SMEs in the United States frequently did not succeed due to financial constraints in their second or third year of operation.

Puhakka (2007) indicated that research on business organisations is switching from the management of existing firms to the creation of new firms. This is because of the importance of new businesses in changing the competition in the business environment. In addition, policy makers have agreed that the creation of new SMEs reduces unemployment and poverty rates, especially in developing countries. Li and Daly (2005) point out that new SMEs trigger competition, stir research, development and innovation, push old firms to improve their efficiency, and result in economic growth, technological upgrading, job creation and welfare improvement.

Fatoki (2014) argues that successful new SMEs are likely to add significant benefits to regional and national economies. The benefits are likely to take the form of new products, new jobs, greater exports and taxation revenues. Bruce, Deskins, Hill, and Rork (2009) found that the number of births of new SMEs adds significantly to a country's GDP. Therefore, new SMEs provide long-term benefits to the local economy. Maas and Herrington (2007) endorse the argument that new SMEs make a significant difference to economic prosperity and that South Africa risks economic stagnation without a high new SME creation rate. Countries that are able to replenish the stock of businesses and jobs and have the capacity to accommodate volatility and turbulence in the entrepreneurial sector are best placed to compete effectively. In countries ranking high in the Global Entrepreneurship Monitor (GEM) analysis, entrepreneurship and new SME creation is an integral and accepted feature of economic and personal life.

The two external financial sources for new SMEs are equity and debt. In Vietnam, external equity in form of stock exchange is not available for new SMEs because they are usually not able to meet the entry requirements of stock exchange. Moreover, venture capitalists often invest in firms at middle or later stages of their life cycle. Venture capital in Vietnam is especially scarce (Scheela \& Nguyen, 2004). External equity in form of venture capital or stock exchange is limited for new SMEs in Vietnam. Le (2013) found that SMEs with a closer bank relationship have a higher probability of receiving a bank loan. However, it is also difficult for firm owners to build up their networks with bank officers. Therefore, new SMEs rely on bank loans and informal credits from friends or relatives for their early stage financing. However, SMEs are generally considered to be riskier than large firms. SMEs confront several barriers in order to access bank loans, such as lack of collaterals, banks' unwillingness to lend to SMEs, and high interest rates. Nguyen and Luu (2013) reported that $75 \%$ of SMEs interviewed would like to seek bank loans but only $30 \%$ of them succeeded. Results from the enterprise survey in Vietnam reveal that $71 \%$ of small firms (5-19 employees) were not able to access bank loans in comparison to $44 \%$ of medium firms (20-99 employees). These numbers show that financial services providing credit for SMEs are insufficient (World Bank, 2015).

\subsection{Determinants of the Access of New SMEs to Bank Loans}

Determinants of access to bank loans could be networking, managerial competence, business information, the sector of the economic activity, firm size and the firm's location. In this section, we review some relevant literature regarding access to bank loans.

Networking in a small firm context is an activity in which entrepreneurially oriented SME owners build and manage personal relationships with particular individuals in their surroundings. Networking is one of the most important means for the access of SME owners to resources or inputs and for them to market their goods and services (Hoang \& Antoncic, 2003; O'Donnell, 2014; Watson, 2011). According to Le and Nguyen (2009), networking with suppliers has a significantly negative correlation to the use of bank loans while networking with customers is positively related to it. Nguyen and Ramachandran (2006) indicated that SMEs having a larger networking were able to receive more trade credit and other resources for their operations, and SMEs that pay more attention to their relationship with banks will incur more debt, especially short-term debt. Fatoki and Odeyemi (2010) found that new SMEs with owners who can rely on previous relationships with banks are significantly more likely to be successful in their credit applications. For China, Li, Meng, Wang, and Zhou (2008) found that private firm owners who are members of the Communist Party are more likely to receive bank loans.

Managerial competencies are sets of knowledge, skills, behaviours and attitudes that contribute to personal 
effectiveness as a manager. Fatoki and Odeyemi (2010) and Fatoki and Asah (2011) found that new SMEs in South Africa managed by owners with a high education level and related business experience are more likely to be successful in their credit application.

Fatoki and Odeyemi (2010) indicated that SMEs with a business plan are more likely to be successful in their credit application than those that do not have a business plan. If SMEs have and can provide more business information, their likelihood of applying for finance increases since they are familiar with regulations and requirements of lenders (banks or credit funds; Fatoki \& Asah, 2011; Kira \& He, 2012).

Access to debt financing is positively related to the sector of a firm. Most of the sources of financing prefer lending to manufacturing sectors while other sectors are rather left unsupported (Kira \& He, 2012). Le (2012) found that industry dummies are statistically significant to the probability of obtaining a bank loan.

Burkart and Ellingsen (2004) showed that a larger firm size tends to provide greater access to long-term debt. This is also supported by Beck and Demirguc-Kunt (2006), Kira and He (2012), and Mulaga (2013). They all found that larger firms have a higher access to debt financing than smaller ones. For South Africa, Fatoki and Odeyemi (2010) and Fatoki and Asah (2011) found that firm size is positively associated with access to finance. The positive relationship between firm size and the access to bank loans is also demonstrated for Vietnam (Le, 2012).

Kira and He (2012) found that a positive relationship between a firm's location and its debt ratio. Firms located in urban areas have a higher possibility to receive bank loans than firms located in rural areas in South Africa (Fatoki \& Asah, 2011; Fatoki \& Odeyemi, 2010).

Another determinant is the maturity of a firm measured in years. A higher age of a firm brings about a positive effect on the probability of getting a bank loan (Fatoki \& Asah, 2011; Kira \& He, 2012; Le, 2012).

\section{Research Methodology}

\subsection{Data Collection}

Data for the study were collected in the Phu Tho province in Northern Vietnam over the course of four months from May to August 2015 using a simple random technique (Creswell, 2009; Khandker, Koolwal, \& Samad, 2010). The province is known as an old industrial area but now a growing number of small and medium sized enterprises chose the province as their location (see table 1). The majority of its population lives in rural areas and supplies many SMEs with a large number of labourers.

Table 1. New Business Registration and Failure in the Phu Tho Province 2012-2016

\begin{tabular}{lccccc}
\hline & 2012 & 2013 & 2014 & 2015 & 2016 \\
\hline - SMEs established & 317 & 464 & 405 & 548 & 717 \\
- SMEs closed down & 140 & 198 & 939 & 496 & 300 \\
- SMEs bankrupted & 23 & 29 & 69 & 46 & 30 \\
\hline
\end{tabular}

Source: The Phu Tho Tax Bureau, 2017.

The overall targeted population in Phu Tho for our study was around 1200 new SMEs (Phu Tho Province, 2015). The Raosoft (Note 1) sample size calculator (margin of error: 5\%; confidence interval: $95 \%$; response distribution: 50\%) suggests a minimum recommended sample size of 292 observations.

Based on the list of new SMEs from the Phu Tho Tax Bureau and the Planning and Investment Department (including telephone numbers and email addresses) covering one city and twelve districts belonging to the Phu Tho province, we took two steps selecting interviewed firms. Firstly, we purposely chose one city and six districts to represent urban and rural areas. Secondly, we randomly selected firms from the list from each selected district-level unit. A total of 350 questionnaires were handed out, 289 (82\%) were returned, $259(74 \%)$ of which were fully completed both in urban and rural areas. Owners or representatives of SMEs were asked several open-ended questions relating to general characteristics of firms, financing, business information, and managerial, networking characteristics. Data were then entered with the SPSS package and analysed with STATA. 

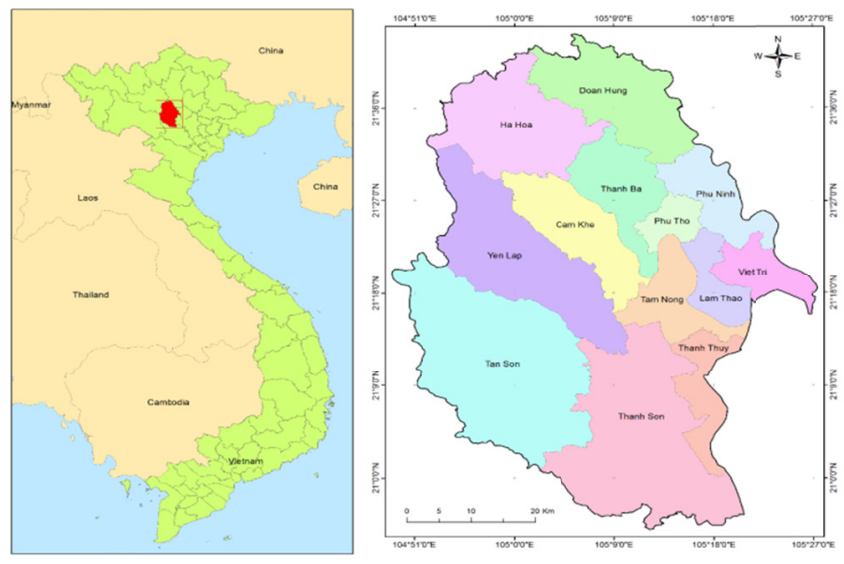

Figure 1. Map of Vietnam (left) and the Phu Tho Province in Northern Vietnam (right)

Source: http://www.phutho.gov.vn

We set up a team of enumerators who are native to the province conducted the survey. They were trained in both data collection methods and the reasons behind each item in the questionnaire in four days. After training activities, the enumerators did a pre-test for the questionnaire with some enterprise owners. The survey covers solely new SMEs defined by capital less than VND 100 billion (USD 4.5 million) or less than 300 employees (The Vietnamese Government, 2009). The enumerators directly contacted the selected new SMEs via email or telephone to make appointments with SME owners. Then the enumerators came to enterprises to hand in the questionnaire, explaining the reasons of conducting the survey. The enumerators had to follow up the surveyed firms and came back to collect the completed questionnaires.

\subsection{Model Specifications and Hypotheses}

We estimated two models: a probit model estimates the probability to receive a bank loan, a tobit model estimates the bank loan ratio as an additional measure. Both models use the same set of explanatory variables. The variable "networking" was combined of four main dimensions (emotional trust, knowledge trust, approachability, and personal sharing). To construct this variable, the firm owners were asked to select the level of relationships between firms and bank's credit official based on a 5-point Likert scale. Factor analysis was employed to build the four dimensions used in the models. Another explanatory variable is managerial competence, also measured by a 5 -point Likert scale $(1=$ very bad; $5=$ very good $)$. These five items have a reliability test with Cronbach's alpha of 0.899 (see appendix 3). The selected independent variables are shown in greater detail in appendix 2.

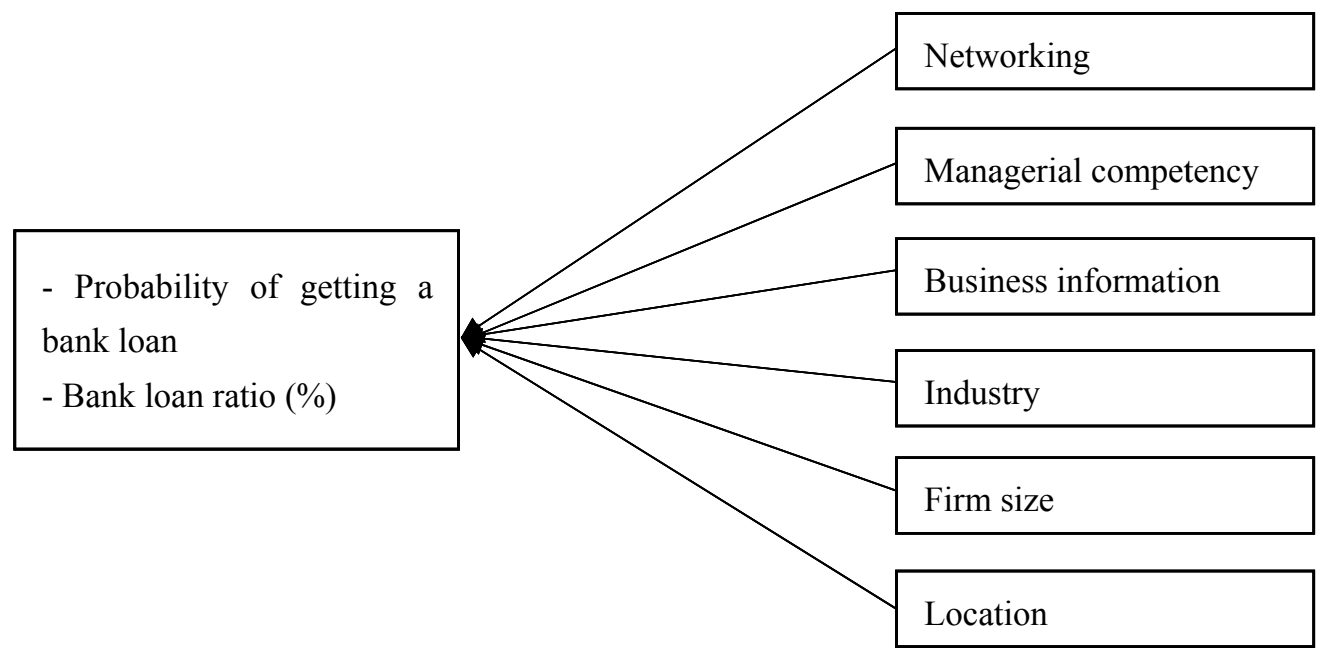

Figure 2. Conceptual framework of the access of new SMEs to bank credit

Source: Own illustration. 
To analyses whether there is a correlation between firms, owners' characteristics and access to bank loans, a simple probit model was applied (1) to find out which factors influence the probability of SMEs successfully getting a bank loan.

Probit model: probability of getting a bank loan

$$
y_{1 i}^{*}=X_{1 i}^{\prime} \beta_{1}+v_{i}
$$

There is a large body of literature on the drivers of access to bank loans $\left(y_{1 i}^{*}\right)$. Most studies prefer a logistic regression (e.g., logit and probit models) to find out how selected independent variables affect the dichotomous variable (Coleman, 2000). Having a bank loan in 2014 is a dummy variable, and $X_{i}$ is a vector of explanatory variables expected to influence the probability of receiving a bank loan. A probit model is suitable for analysing regression where the dependent variable only has two values (Greene, 2012; Wooldridge, 2010). Explanatory variables are networking, managerial competency, business information, firm industry, firm size, firm location, and owners'/managers' characteristics.

Secondly, we divided the sample into two groups (one that did and one that did not have a bank loan in the fiscal year 2014). To examine the intensity of a bank loan (the percentage of bank loans), a tobit model was applied (2).

$$
\begin{aligned}
y_{2 i}^{*} & =X_{2 i}^{\prime} \beta_{2}+\mu_{i}, \\
y_{2 i} & =\left\{\begin{array}{l}
y_{2 i}^{*}, \text { if } X_{2 i}^{\prime} \beta_{2}+\mu_{i}>0 \\
0, \text { otherwise }
\end{array}\right.
\end{aligned}
$$

Following Blackwell and Winter (1997), Le and Nguyen (2009) and Mulaga (2013), we used the bank loan ratio measured by total bank credit over the total capital stock of the enterprise as a dependent variable in our model. This ratio does not depend on firm size, thus it is suitable for measuring the ability of access to bank loans. As the bank loan ratio is a continuous dependent variable including zero value, we applied a tobit model (Verbeek, 2004). In our study, a substantial part of the SMEs has a bank loan ratio equal to zero while the rest of our sample has a positive value.

The bank loan ratio of new SMEs is given by $\mathrm{y}_{2 \mathrm{i}}^{*}$. $\mathrm{X}_{2 \mathrm{i}}$ is the vector of explanatory variables expected to have an influence on the bank loan ratio. The two error terms $v_{i}$ and $\mu_{i}$ are expected to be independent and normally distributed with $\mathrm{v}_{\mathrm{i}} \approx \mathrm{N}(0,1) ; \mu_{\mathrm{i}} \approx \mathrm{N}\left(0, \sigma^{2}\right)$.

Based on the literature review and our conceptual framework, we hypothesise:

- H1: there is a positive relationship between the level of networking and the access to bank loans for new SMEs.

- H2: there is a positive relationship between the managerial competence and the access to bank loans for new SMEs.

- H3: there is a positive relationship between business information and the access to bank loans for new SMEs.

- H4: new SMEs in trade and service have more credit constraints than those in manufacturing.

- H5: new micro and small firms have more credit constraints than new medium ones.

- H6: new SMEs in rural areas have more credit constraints than the ones in urban areas.

\section{Results and Discussions}

\subsection{Characteristics of the Sample}

Table 2 presents descriptive statistics of the characteristics of the SMEs in our sample of 259 new SMEs, $71 \%$ of which were companies with limited liability, $20 \%$ were shareholding companies, and only $9 \%$ were private companies. The number of employees in new SMEs range from 1 to 125 . The capital stock of SMEs varied between VND (Note 2) 30 million to 104423 million (USD 1300 to 4700000 ). There was $47 \%$ of the companies focus on trading while $31 \%$ concentrate mainly on service, and only $22 \%$ focus on manufacturing. In terms of location, $53 \%$ of the firms are located in an urban area, and $47 \%$ in rural areas.

Regarding the owners' characteristics, $76 \%$ of the owners are male, and $24 \%$ are female. About $50 \%$ of the owners have a university degree. The owners' management experience ranges from 1 to 20 years. 
Table 2. Descriptive Statistics of the Entire Sample

\begin{tabular}{|c|c|c|}
\hline & Absolute Number & Percentage $(\%)$ \\
\hline \multicolumn{3}{|l|}{ Legal Status } \\
\hline - Shareholding companies & 52 & 20.08 \\
\hline - Limited liability companies & 183 & 70.66 \\
\hline - Private companies & 24 & 9.27 \\
\hline \multicolumn{3}{|l|}{ Firm Size (number of employees) } \\
\hline - Range & $1-125$ & \\
\hline - Mean & 11.143 & \\
\hline - Std. deviation & 15.338 & \\
\hline \multicolumn{3}{|l|}{ Total Capital (in million VND) } \\
\hline - Range & $30-104423$ & \\
\hline - Mean & 3970.486 & \\
\hline - Std. deviation & 8801.347 & \\
\hline \multicolumn{3}{|l|}{ Firm Industry } \\
\hline - Trade enterprises & 120 & 46.51 \\
\hline - Service enterprises & 80 & 31.01 \\
\hline - Manufacturing enterprises & 58 & 22.48 \\
\hline \multicolumn{3}{|l|}{ Location } \\
\hline - Urban area & 138 & 53.28 \\
\hline - Rural area & 121 & 46.72 \\
\hline \multicolumn{3}{|l|}{ Owner Gender } \\
\hline - Male & 196 & 75.68 \\
\hline - Female & 63 & 24.32 \\
\hline \multicolumn{3}{|l|}{ Owner Education } \\
\hline - Have a university degree & 129 & 49.81 \\
\hline - Do not have a university degree & 130 & 50.19 \\
\hline \multicolumn{3}{|l|}{ Owner Experience } \\
\hline - Range & $1-20$ & \\
\hline - Mean & 4.822 & \\
\hline - Std. deviation & 4.264 & \\
\hline \multicolumn{3}{|l|}{ Access to Bank Loans } \\
\hline - Have not borrowed & 165 & 63.71 \\
\hline - Have borrowed & 94 & 36.29 \\
\hline Bank Loan/Capital & $94 *$ & \\
\hline - Range & $0.028-0.833$ & \\
\hline - Mean & 0.359 & \\
\hline - Std. deviation & 0.216 & \\
\hline $\mathrm{N}$ & 259 & \\
\hline
\end{tabular}

Regarding the access to bank loans, about $36 \%$ of firms received loans from banks while $64 \%$ did not. The range of bank loans over the total capital defined as the bank loan ratio ranged from 0.03 to 0.83 .

Table 3 presents mean values and T-tests of the mean difference (Note 3) of the variables in the regression analysis. Using T-tests, we found that most of the variables are significantly different (except those variables regarding the owners' characteristics) between bank loan recipients and non-recipients. Overall, the recipients seem to have more experience in management skills and are more active in networking with banks. Furthermore, recipient SMEs have significantly more business plans (56\%) than non-recipient SMEs (only $25 \%$ had a plan). Finally, recipient SMEs have a larger firm size (measured by number of employees) than those which did not receive a bank loan. 
Table 3. Descriptive statistics for recipients of bank loans

\begin{tabular}{|c|c|c|c|}
\hline Variables & $\begin{array}{l}\text { Non-recipients } \\
\quad(\mathrm{N}=165)\end{array}$ & $\begin{array}{l}\text { Recipients } \\
(\mathrm{N}=94)\end{array}$ & Differences \\
\hline Trade (1 = SME focuses on trading) & 0.418 & 0.553 & $-0.135^{* *}$ \\
\hline Service ( 1 = SME focuses on service) & 0.376 & 0.191 & $0.184^{* * *}$ \\
\hline Plan $(1=$ yes $)$ & 0.255 & 0.564 & $-0.309^{* * *}$ \\
\hline Age (in years) & 41.091 & 42.894 & -1.803 \\
\hline Gender $(1=$ male $)$ & 0.758 & 0.755 & 0.002 \\
\hline Education level $(1=$ having a university degree $)$ & 0.491 & 0.511 & -0.020 \\
\hline Manager experience (in years) & 4.461 & 5.457 & $-0.997^{*}$ \\
\hline Manager skills $\mathrm{s}^{\mathrm{a}}$ & 3.610 & 3.653 & -0.043 \\
\hline Firm size $(1$ = small firm $)$ & 0.200 & 0.383 & $-0.183^{* * *}$ \\
\hline Emotional trust ${ }^{\mathrm{b}}$ & 1.742 & 2.149 & $-0.407^{* * *}$ \\
\hline Knowledge trust ${ }^{\mathrm{b}}$ & 2.995 & 3.779 & $-0.784^{* * *}$ \\
\hline Approachability ${ }^{\mathrm{b}}$ & 3.822 & 4.121 & $-0.298^{* *}$ \\
\hline Personal sharing ${ }^{\mathrm{b}}$ & 2.409 & 2.654 & $-0.245^{*}$ \\
\hline Location (1 = located in urban area) & 0.539 & 0.521 & 0.018 \\
\hline$N$ & 259 & & \\
\hline \multicolumn{4}{|l|}{ Note: ${ }^{*} \mathrm{p}<0.10,{ }^{* *} \mathrm{p}<0.05,{ }^{* * *} \mathrm{p}<0.01$} \\
\hline \multicolumn{4}{|c|}{ a: Those variables were measured by using a 5 -point Likert scale $(1=$ very bad; $5=$ very good $)$} \\
\hline \multicolumn{4}{|c|}{ b: Those variables were measured by using a 5 -point Likert scale ( $1=$ strongly disagree; $5=$ strongly agree $)$} \\
\hline
\end{tabular}

In order to discover the multicollinearity issues of selected independent variables in the model, we run a correlation matrix (see appendix 4). From the matrix, we found that service is positively correlated with the trade sector. Educational level is negatively associated with age. Manager experience is negatively correlated with the service sector but positively associated with age. Manager skills are correlated with the education level and manager experience. Firm size is negatively correlated with the trade sector but positively associated with the business plan and manager skills. Emotional trust has positive associations with the business plan. Knowledge trust is also positively correlated with the business plan, age, firm size and emotional trust. Approachability is negatively correlated with age and knowledge trust; however, it is positively associated with emotional trust. Interestingly, personal sharing has positive associations with manager skills, emotional trust, knowledge trust, and approachability. Finally, location is negatively correlated with plan and gender, but has a positive relation to the educational level. Since selected explanatory variables are not highly correlated, all variables are put in the regression models in the next two sections.

\subsection{Determinants of Receiving a Bank Loan}

The empirical results of the probit model are presented in table 4 . Overall, the model can explain $20.6 \%$ of the change of probability of receiving a loan $\left(\mathrm{R}^{2}=0.206\right.$ at $1 \%$ significant level). This implies that the set of selected explanatory variables reliably distinguishes between firms with a bank loan and firms without a bank loan. The marginal effects (ME) of each model helps to better understand the magnitude of the effect of an independent variable on the probability of receiving bank loans.

Table 4. Factors influencing credit access by probit model

\begin{tabular}{lcccccc}
\hline \multirow{2}{*}{ Variables } & \multicolumn{2}{c}{ Full sample } & \multicolumn{2}{c}{ Urban Firms } & \multicolumn{2}{c}{ Rural Firms } \\
Coef & ME & Coef & ME & \multicolumn{2}{c}{ Coef } & ME \\
\hline Trade (1 = SME focuses on trading) & 0.24426 & 0.0716 & 0.24382 & 0.0743 & 0.30998 & 0.0803 \\
& $(0.25313)$ & $(0.0735)$ & $(0.38586)$ & $(0.117)$ & $(0.37163)$ & $(0.0955)$ \\
Service (1 = SME focuses on service) & -0.29480 & -0.0864 & -0.07689 & -0.0234 & -0.62186 & -0.161 \\
& $(0.25490)$ & $(0.0744)$ & $(0.34238)$ & $(0.104)$ & $(0.42896)$ & $(0.109)$ \\
Plan (1 = yes) & $0.55919^{* * *}$ & $0.164^{* * *}$ & $0.63965^{* *}$ & $0.195^{* *}$ & $0.59068^{* *}$ & $0.153^{* *}$ \\
& $(0.19207)$ & $(0.0534)$ & $(0.27449)$ & $(0.0789)$ & $(0.27616)$ & $(0.0692)$ \\
Age (in years) & -0.00360 & -0.00106 & 0.00068 & 0.000209 & 0.00203 & 0.000527 \\
& $(0.01067)$ & $(0.00312)$ & $(0.01463)$ & $(0.00446)$ & $(0.01606)$ & $(0.00416)$ \\
Gender (1 = male) & -0.00339 & -0.000995 & 0.14026 & 0.0428 & -0.32367 & -0.0839 \\
\hline
\end{tabular}




\begin{tabular}{|c|c|c|c|c|c|c|}
\hline & $(0.21739)$ & $(0.0637)$ & $(0.27311)$ & $(0.0832)$ & $(0.36842)$ & $(0.0957)$ \\
\hline \multirow{2}{*}{$\begin{array}{l}\text { Education level ( } 1=\text { having a university } \\
\text { degree })\end{array}$} & 0.04421 & 0.0130 & -0.02929 & -0.00893 & 0.16810 & 0.0436 \\
\hline & $(0.18345)$ & $(0.0538)$ & $(0.24278)$ & $(0.0740)$ & $(0.29078)$ & $(0.0751)$ \\
\hline \multirow[t]{2}{*}{ Manager experience (in years) } & 0.02767 & 0.00811 & 0.02694 & 0.00821 & 0.02931 & 0.00759 \\
\hline & $(0.02260)$ & $(0.00658)$ & $(0.03280)$ & $(0.00997)$ & $(0.03386)$ & $(0.00867)$ \\
\hline \multirow[t]{2}{*}{ Manager skills ${ }^{\mathrm{a}}$} & -0.08085 & -0.0237 & -0.12922 & -0.0394 & -0.01543 & -0.00400 \\
\hline & $(0.16799)$ & $(0.0493)$ & $(0.24379)$ & $(0.0745)$ & $(0.24340)$ & $(0.0630)$ \\
\hline \multirow[t]{2}{*}{ Firm size ( 1 = small firm $)$} & $0.40152 *$ & $0.118^{*}$ & 0.53135 & $0.162 *$ & 0.15731 & 0.0408 \\
\hline & $(0.22119)$ & $(0.0631)$ & $(0.32469)$ & $(0.0956)$ & $(0.33304)$ & $(0.0858)$ \\
\hline \multirow[t]{2}{*}{ Emotional trust $^{\mathrm{b}}$} & $0.29371^{* *}$ & $0.0861 * *$ & $0.34600^{*}$ & $0.105^{*}$ & 0.27140 & 0.0703 \\
\hline & $(0.14378)$ & $(0.0410)$ & $(0.20924)$ & $(0.0610)$ & $(0.19382)$ & $(0.0498)$ \\
\hline \multirow[t]{2}{*}{ Knowledge trust ${ }^{\mathrm{b}}$} & $0.26741 * * *$ & $0.0784 * * *$ & 0.14178 & 0.0432 & $0.43111 * * *$ & $0.112 * * *$ \\
\hline & $(0.09815)$ & $(0.0280)$ & $(0.14889)$ & $(0.0453)$ & $(0.13230)$ & $(0.0313)$ \\
\hline \multirow[t]{2}{*}{ Approachability ${ }^{\mathrm{b}}$} & $0.28380 * *$ & $0.0832 * *$ & 0.20167 & 0.0615 & $0.37374 *$ & $0.0968 * *$ \\
\hline & $(0.12563)$ & $(0.0355)$ & $(0.17494)$ & $(0.0521)$ & $(0.19193)$ & $(0.0473)$ \\
\hline \multirow[t]{2}{*}{ Personal sharing ${ }^{\mathrm{b}}$} & 0.04229 & 0.0124 & 0.04068 & 0.0124 & 0.06015 & 0.0156 \\
\hline & $(0.11472)$ & $(0.0336)$ & $(0.16021)$ & $(0.0488)$ & $(0.16555)$ & $(0.0428)$ \\
\hline \multirow[t]{2}{*}{ Location ( 1 = located in urban area) } & -0.04278 & -0.0125 & & & & \\
\hline & $(0.18599)$ & $(0.0545)$ & & & & \\
\hline \multirow[t]{2}{*}{ Constant } & $-3.11712 * * *$ & & $-2.67559^{*}$ & & $-4.21327 * * *$ & \\
\hline & $(1.00839)$ & & $(1.48796)$ & & $(1.48498)$ & \\
\hline Observations & 259 & & 138 & & 121 & \\
\hline $\mathrm{R}^{2}$ & $0.2059 * * *$ & & 0.1709 & & $0.2964 * * *$ & \\
\hline Wald chi2 & 51.51 & & 21.89 & & 42.30 & \\
\hline
\end{tabular}

Note. robust standard errors in parentheses. $* * * \mathrm{p}<0.01, * * \mathrm{p}<0.05, * \mathrm{p}<0.1$.

SMEs which have a business plan have a $16.4 \%$ higher probability to receive a bank loan compared to new SMEs without a business plan. This supports hypothesis H3. New SMEs' lack for data on past business history and low financial information as well as limited ability to put together a business plan make them more likely to fail in acquiring a bank loan.

Among the firms' characteristics, firm size had a significantly positive effect on the probability of getting a bank loan, supporting hypothesis H5. The bigger firms with more assets as collateral are $11.8 \%$ more likely to obtain a bank loan.

In addition, variables such as emotional trust, knowledge trust, and approachability of bank officers all have a statistically positive influence on the probability of getting a bank loan. It is not surprising that new SMEs with a good relationship to banks are more likely to receive a bank loan, supporting hypothesis H1.

In order to further analyse the effect of location on the probability of access to bank loans, we ran two additional models with independent variables (see table 4). Overall, there is no difference in our sample between SMEs located in rural and those located in urban areas, whereby hypothesis H6 is not supported.

\subsection{Factors Influencing the Bank Loan Ratio}

Factors influencing the bank loan ratio are shown in table 5. The estimated tobit model was employed to examine whether selected explanatory variables such managerial competency, business information, networking, industry, firm size, or location influence the bank loan ratio. The model is statistically significant with $\mathrm{R}^{2}=0.217$ $\left(\mathrm{Chi}^{2}=0.0000\right)$.

As expected, a business plan positively influences the bank loan ratio at a highly significant level. The bank loan ratio of those new SMEs that had a business plan is $19 \%$ higher than that of SMEs without one.

The results for emotional trust (Coef $=0.11868$ at $5 \%$ significant level), knowledge trust (Coef $=0.09677$ at $1 \%$ significant level), and approachability of bank officers (Coef $=0.10570$ at $1 \%$ significant level) were both positively and significantly related to the bank loan ratio. 
Table 5. Factors Influencing the Bank Loan Ratio According to the Tobit Model

\begin{tabular}{|c|c|}
\hline Variables & Coefficients \\
\hline \multirow[t]{2}{*}{ Trade (1 = SME focus on trading $)$} & 0.10123 \\
\hline & $(0.08344)$ \\
\hline \multirow[t]{2}{*}{ Service $(1=$ SME focus on service $)$} & -0.11198 \\
\hline & $(0.09488)$ \\
\hline \multirow[t]{2}{*}{ Plan $(1=$ yes $)$} & $0.19449^{* * *}$ \\
\hline & $(0.06715)$ \\
\hline \multirow[t]{2}{*}{ Age (in years) } & 0.00014 \\
\hline & $(0.00380)$ \\
\hline \multirow[t]{2}{*}{ Gender $(1=$ male $)$} & 0.02849 \\
\hline & $(0.07528)$ \\
\hline \multirow[t]{2}{*}{ Education level ( 1 = having a university degree $)$} & 0.02738 \\
\hline & $(0.06603)$ \\
\hline \multirow[t]{2}{*}{ Manager experience (in years) } & 0.00635 \\
\hline & $(0.00814)$ \\
\hline \multirow[t]{2}{*}{ 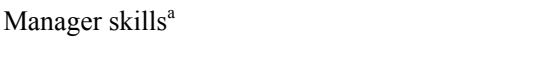 } & -0.04471 \\
\hline & $(0.05918)$ \\
\hline \multirow[t]{2}{*}{ Firm size $(1=$ small firm $)$} & 0.06265 \\
\hline & $(0.07506)$ \\
\hline \multirow[t]{2}{*}{ Emotional trust $^{\mathrm{b}}$} & $0.11868 * *$ \\
\hline & $(0.04656)$ \\
\hline \multirow[t]{2}{*}{ Knowledge trust $\mathrm{t}^{\mathrm{b}}$} & $0.09677 * * *$ \\
\hline & $(0.03550)$ \\
\hline \multirow[t]{2}{*}{ Approachability $^{\mathrm{b}}$} & $0.10570 * * *$ \\
\hline & $(0.03981)$ \\
\hline \multirow[t]{2}{*}{ Personal sharing ${ }^{\mathrm{b}}$} & 0.01054 \\
\hline & $(0.03669)$ \\
\hline \multirow[t]{2}{*}{ Location ( $1=$ located in urban area) } & -0.02771 \\
\hline & $(0.06724)$ \\
\hline \multirow[t]{2}{*}{ Constant } & $-1.13684 * * *$ \\
\hline & $(0.33698)$ \\
\hline Observations & 259 \\
\hline $\mathrm{R}^{2}$ & 0.2172 \\
\hline Wald chi2 & 0.0000 \\
\hline \multirow[t]{2}{*}{ Sigma } & $0.40295 * * *$ \\
\hline & $(0.03337)$ \\
\hline
\end{tabular}

Note. standard errors in parentheses. ${ }^{* * *} \mathrm{p}<0.01, * * \mathrm{p}<0.05,{ }^{*} \mathrm{p}<0.1$

\subsection{Reasons for not Receiving a Bank Loan}

Table 6 summaries the reasons for surveyed SMEs not getting a bank loan.

Table 6. Reasons for New SMEs without Credit

\begin{tabular}{lcc}
\hline & Absolute Number & Percentage (\%) \\
\hline Applied for a bank loan but did not get all financing requested & 55 & 100 \\
- The application was rejected & 44 & 80 \\
- Refused because interest rates are too high & 9 & 16.36 \\
- Refused because of insufficient size of loan & 1 & 1.82 \\
- Other & 1 & 1.82 \\
Did not apply for any bank loan & 110 & 100 \\
- Firm has sufficient internal funds & 21 & 19.09 \\
- Application procedures for loans or lines of credit are complex & 13 & 11.82 \\
- Interest rates are not favourable & 15 & 13.64 \\
- Collateral requirements are too high & 13 & 11.82 \\
\hline
\end{tabular}




\begin{tabular}{lcc}
\hline - Size of loan is insufficient & 4 & 3.64 \\
- Maturity of loan is insufficient & 2 & 1.82 \\
- Do not think it would be approved & 42 & 38.18 \\
- Other & 0 & 0 \\
N (number of observations) & 165 & \\
\hline
\end{tabular}

Source: authors' calculations from the survey in 2015.

There are many financing constraints such as high interest rates, complex application processes, high collateral requirement from banks, and the lack of a business plan. In our sample 42.3\% (110 firms) of new SMEs did not apply for any bank loan. Reasons include the complexity of loan application procedures, a high interest rate and high collateral requirements. About $19 \%$ of those firms are self-financed in the first years of operation. Interestingly, those new SMEs that did not apply for any bank loan believed that they would not be successful. In general, they had a short networking with banks officers, a lack of collateral assets, none or poor business plans and a low ability to write the application.

The proportion of new businesses that applied for but did not receive a loan was about $21.2 \%$ of the total sample. In order to understand why new SMEs failed to obtain a bank loan despite having applied for it, we conducted a focus group discussion shortly after the survey with 10 owners of SMEs. The reasons for the rejection of loan applications were: (i) low level of collateral; (ii) banks do not trust in new SMEs; (iii) poor networking due to the lack of information between firms and banks; (iv) lack of support from bank officers to help new SMEs with their application documents.

A focus group discussion with bank officers also took place after our survey. Five commercial bank officers in the province who work closely with new SMEs participated in the discussion illustrating the reasons why banks rejected to provide financial means to firms. The main findings were: (i) inefficient production or business project; (ii) lack of collateral and assets' insurance; (iii) lack of audited financial reports.

\section{Conclusions and Policy Implications}

This paper has investigated factors influencing bank financing to new SMEs in Vietnam. We mainly focused on new SMEs in the Phu Tho province in Northern Vietnam and their current access to bank loans. The literature suggests many constraints for obtaining sufficient bank loans such as lack of managerial skills, weak relationship with banks, and high transactions costs. We applied several specifications such as descriptive statistics, and probit and tobit regressions.

Overall, the results support our hypotheses which included business information, managerial competency, networking and firm characteristics. Having a good business plan positively influences the probability of getting a bank loan. New SMEs with a business plan are more likely to receive a bank loan as opposed to SMEs without a business plan; further analysis about determining the bank loan ratio also reveals that a business plan is important. Firm size has a positive effect on receiving a bank loan. New small firms are more likely to get a bank loan in comparison with new micro firms. However, firm size is not significant with regard to the bank loan ratio in the tobit model. To avoid lending risks, banks demand collateral from micro firms or provide a loan with a high interest rate. Unfortunately, micro firms do not usually have assets to offer as bank loan collaterals. The results also indicate that networking factors positively and significantly influence the grant of a bank loan and the bank loan ratio. In addition, there are about $60 \%$ of new SMEs in our sample that did not get any access to formal external credit sources. This fact could lead to the failure of new firms due to the lack of sufficient capital to keep their business in operation. Based on these findings, we argue that credit denial mainly depends on poor business plans. This is of particular importance for managers of new small businesses.

As the rate of failure of new SMEs is high, more support from the government could help SMEs to grow, to provide jobs and to contribute to regional growth. It can be suggested that the government should encourage the development of SMEs by implementing credit guarantee programmes, focusing more on credit interest policies (subsidising), and improving owners' capacity for management, especially in start-up companies. The government should pay more attention to the financing market and provide concrete proper financial information (availability, interest rate, requirements, and supported policies). It is recommended that start-up training programmes should focus more on owners or managers of new SMEs to assist them in developing their business plans properly. It is also important for new firm owners to take writing their business plan more seriously since it will be the key principle for their success in doing business, as well as pay more attention on the credit application and compliance process. 
We acknowledge several limitations of our research. The access to bank loans (recipients and non-recipients) might lead to biased and inconsistent coefficients. In such a case, the advanced method like propensity score matching that controls the selection bias could be employed. It is also important to explore the long-term effect of the access to bank loans on firm performance by using panel data.

\section{Acknowledgements}

The authors acknowledge financial support from the Vietnamese Government (Steering Committee of Programme 165) and the Göttingen Graduate School of Social Sciences (GGG). We are also grateful to the Phu Tho Tax Bureau and the Hung Vuong University (HVU) for their kind cooperation to conduct the fieldwork.

\section{References}

Ayodeji, A. R., \& Balcioglu, H. (2010). Financing industrial development in Nigeria. A case study of the small and medium enterprises in Kwara State. Global Journal of Management and Business Research, 10(3), 46-60.

Ayyagari, M., Demirgüç-Kunt, A., \& Maksimovic, V. (2006). How Important Are Financing Constraints? The role of finance in the business environment. World Bank Policy Research Working Paper 3820.

Beck, T. (2007). Financing Constraints of SMEs in Developing Countries: Evidence, Determinants and Solutions. KDI 36th Anniversary International Conference.

Beck, T., \& Demirguc-Kunt, A. (2006). Small and medium-size enterprises: Access to finance as a growth constraint. Journal of Banking \& Finance, 30, 2931-2943. https://doi.org/10.1016/j.jbankfin.2006.05.009

Beck, T., Demirguc-Kunt, A., \& Levine, R. (2005). SMEs, Growth, and Poverty Cross-Country Evidence. Journal of Economic Growth, 10, 199-229. https://doi.org/10.1007/s10887-005-3533-5

Beck, T., Demirgüç-Kunt, A., \& Maksimovic, V. (2005). Financial and Legal Constraints to Growth: Does Firm Size Matter? The Journal of Finance, 60(1), 137-177. https://doi.org/10.1111/j.1540-6261.2005.00727.x

Blackwell, D., \& Winter, D. (1997). Banking relationships and the effect of monitoring on loan pricing. The Journal of Financial Research, 20(2), 275-289. https://doi.org/10.1111/j.1475-6803.1997.tb00249.x

Bruce, D., Deskins, J., Hill, B., \& Rork, J. (2009). (Small) Business Activity and State Economic Growth: Does Size Matter? Regional Studies, 43(2), 229-245. https://doi.org/10.1080/00343400701808915

Burkart, M., \& Ellingsen, T. (2004). In-Kind Finance: A Theory of Trade Credit. The American Economic Review, 94(3), 569-590. https://doi.org/10.1257/0002828041464579

Chandler, V. (2012). The economic impact of the Canada small business financing program. Small Business Economics, 39(1), 253-264. https://doi.org/10.1007/s11187-010-9302-7

Coleman, S. (2000). Access to capital and terms of credit: A comparison of men- and women-owned small businesses. Journal of Small Business Management, 38(3), 37-52.

Creswell, J. W. (2009). Research Design: Qualitative, Quantitative, and Mixed Methods Approaches (3rd): The United States of America: SAGE.

Fatoki, O. (2014). The Causes of the Failure of new small and medium enterprises in South Africa. Mediterranean Journal of Social Sciences, 5(20), 922-927. https://doi.org/10.5901/mjss.2014.v5n20p922

Fatoki, O., \& Asah, F. (2011). The Impact of Firm and Entrepreneurial Characteristics on Access to Debt Finance by SMEs in King Williams' Town, South Africa. International Journal of Business and Management, 6(8), 170-179. https://doi.org/10.5539/ijbm.v6n8p170

Fatoki, O., \& Odeyemi, A. (2010). Which New Small and Medium enterprises in South Africa have access to bank Credit? International Journal of Business and Management, 5(10), 128-136. https://doi.org/10.5539/ijbm.v5n10p128

Greene, W. H. (2012). Econometric Analysis (7th ed.). Boston, Pearson.

Hemert, P. V., Nijkamp, P., \& Masurel, E. (2013). From innovation to commercialization through networks and agglomerations: Analysis of sources of innovation, innovation capabilities and performance of Dutch SMEs. The Annals of Regional Science, 50(2), 425-452. https://doi.org/10.1007/s00168-012-0509-1

Hoang, H., \& Antoncic, B. (2003). Network-based research in entrepreneurship. Journal of Business Venturing, 18(2), 165-187. https://doi.org/10.1016/S0883-9026(02)00081-2

Hu, M. W., \& Schive, C. (1998). The Changing Competitiveness of Taiwan's Manufacturing SMEs. Small Business Economics, 11, 315-326. https://doi.org/10.1023/A:1007996701665 
Khandker, S. R., Koolwal, G. B., \& Samad, H. A. (2010). Handbook on Impact Evaluation: Quantitative Methods and Practices. Washington DC 20433: The World Bank.

Kira, A. R., \& He, Z. (2012). The Impact of Firm Characteristics in Access of Financing by Small and Medium-sized Enterprises in Tanzania. International Journal of Business and Management, 7(24), 108-119. https://doi.org/10.5539/ijbm.v7n24p108

Le, B., \& Nguyen, V. (2009). The Impact of Networking on Bank Financing: The Case of Small and Medium-Sized Enterprises in Vietnam. Entrepreneurship Theory and Practice, 33(4), 867-887. https://doi.org/10.1111/j.1540-6520.2009.00330.x

Le, P. N. M. (2012). What Determines the Access to Credit by SMEs? A Case Study in Vietnam. Journal of Management Research, 4(4), 90-115. https://doi.org/10.5296/jmr.v4i4.1838

Le, T. B. N. (2013). Banking Relationship and Bank Financing: The Case of Vietnamese Small and Medium-sized Enterprises. Journal of Economics and Development, 15(1), 74-90.

Lee, S., Park, G., Yoon, B., \& Park, J. (2010). Open innovation in SMEs - An intermediated network model. Research Policy, 39(2), 290-300. https://doi.org/10.1016/j.respol.2009.12.009

Li, H., \& Daly, V. (2005). Convergence of Chinese regional and provincial economic performance: An empirical investigation. International Journal of Development Issues, 4(1), 49-69. https://doi.org/10.1108/eb045848

Li, H., Meng, L., Wang, Q., \& Zhou, L.-A. (2008). Political connections, financing and firm performance: Evidence from Chinese private firms. Journal of Development Economics, 87(2), 283-299. https://doi.org/10.1016/j.jdeveco.2007.03.001

Luong, H., Pham, H., Le, H., Doan, N., \& Doan, Q. (2016). Global Entrepreneurship Monitor Vietnam Report. Retrieved from http://www.gemconsortium.org/country-profile/119

Maas, G., \& Herrington, M. (2007). Global Entrepreneurship Monitor South African Report. Retrieved from http://www.gsb.uct.ac.za/files/gem2007.pdf

Malhotra, M., Chen, Y., Criscuolo, A., Fan, Q., Hamel L.L., \& Savchenko, Y. (2007). Expanding Access to Finance. World Bank Institute, Learning Resources Series.

Mulaga, A. N. (2013). Analysis of External Financing Use: A Study of Small and Medium Enterprises in Malawi. International Journal of Business and Management, 8(7), 55-64. https://doi.org/10.5539/ijbm.v8n7p55

Neumark, D., Wall, B., \& Zhang, J. (2011). Do Small Businesses Create More Jobs? New Evidence for The United States from the National Establishment Time Series. The Review of Economics and Statistics, 93(1), 16-29. https://doi.org/10.1162/REST_a_00060

Nguyen, N., \& Luu, N. T. H. (2013). Determinants of Financing Pattern and Access to Formal -Informal Credit: The Case of Small and Medium Sized Enterprises in Viet Nam. Journal of Management Research, 5(2), 240-259. https://doi.org/10.5296/jmr.v5i2.3266

Nguyen, T. D. K., \& Ramachandran, N. (2006). Capital Structure in Small and Medium sized Enterprises: The Case of Vietnam. Asean Economic Bulletin, 23(2), 192-211. https://doi.org/10.1355/AE23-2D

Nguyen, V., Le, N., \& Freeman, J. (2006). Trust and Uncertainty: A Study of Bank Lending to Private SMEs in Vietnam: A Study of Bank Lending to Private SMEs in Vietnam. Asia Pacific Business Review, 12(4), 547-568. https://doi.org/10.1080/13602380600571260

O'Donnell, A. (2014). The Contribution of Networking to Small Firm Marketing. Journal of Small Business Management, 52(1), 164-187. https://doi.org/10.1111/jsbm.12038

OECD. (2004). Promoting SMEs for Development. 2nd OECD Conference of Ministers Responsible for Small and Medium-Sized Enterprises. Retrieved from http://www.oecd.org/cfe/smes/31919278.pdf

Phu Tho Province. (2015). Statistical Year Book of Phu Tho. Retrieved from http://thongkephutho.vn/index.php/news/Nien-Giam/Nien-giam-Thong-ke-tinh-Phu-Tho-nam-2014-tom-tat $-253 . h t m l$

Puhakka, V. (2007). Effects of Opportunity Discovery Strategies of Entrepreneurs on Performance of New Ventures. Journal of Entrepreneurship, 16(1), 19-51. https://doi.org/10.1177/097135570601600102

Reynolds. (1987). New firms: Societal contribution versus survival potential. Journal of Business Venturing, 2(3), 231-246. https://doi.org/10.1016/0883-9026(87)90011-5 
Robb, A. M., \& Robinson, D. T. (2013). The Capital Structure Decisions of New Firms. Review of Financial Studies, 27(1), 153-179. https://doi.org/10.1093/rfs/hhs072

Scheela, W., \& Nguyen, V.-D. (2004). Venture capital in a transition economy: The case of Vietnam. Venture Capital, 6(4), 333-350. https://doi.org/10.1080/1369106042000258508

The General Statistics Office of Vietnam. (2014). Statistical Yearbook of Vietnam. Retrieved from Ha Noi

The United Nations. (2001). Improving the Competitiveness of SMEs in Developing Countries: The Role of Finance to Enhance Enterprise Development. United Nations Conference on Trade and Development.

The Vietnamese Government. (1986). Economic reform program dated in December 1986 at the Sixth National Congress. Retrieved from $\mathrm{http} / / /$ www.lichsuvietnam.vn/home.php?option=com_content\&task=view\&id=1162\&Itemid=5

The Vietnamese Government. (1990). Private Enterprise Law dated 21/12/1990. Retrieved from http://thuvienphapluat.vn/van-ban/Doanh-nghiep/Luat-Doanh-nghiep-tu-nhan-1990-48-LCT-HDNN8-3805 4.aspx

The Vietnamese Government. (2005). Enterprise Law dated 28/11/2005. Retrieved from http://tailieu.vn/doc/luat-doanh-nghiep-viet-nam-bang-tieng-anh-enterprise-law-355565.html

The Vietnamese Government. (2009). Decree No. 56/2009/ND-CP dated 30/06/2009 support state assistance for development of small and medium enterprises. Retrieved from http://thuvienphapluat.vn/van-ban/Doanh-nghiep/Nghi-dinh-56-2009-ND-CP-tro-giup-phat-trien-doanh-ngh iep-nho-vua-90635.aspx

The Vietnamese Government. (2013). Decision No. 58/QD-TTg dated 15/10/2013 The regulations on establishment, organization and operation of credit guarantee funds for SMEs in provinces and cities. Retrieved from http://thuvienphapluat.vn/van-ban/Doanh-nghiep/Quyet-dinh-58-2016-QD-TTg-tieu-chi-phan-loai-doanh-n ghiep-nha-nuoc-336059.aspx

Verbeek, M. (2004). A Guide to Modern Econometrics (2nd): Chichester: John Wiley \& Sons.

Vo, T. T., T.C. Tran, V. D. Bui, \& D. C. Trinh. (2011). Small and Medium Enterprises Access to Finance in Vietnam: Small and Medium Enterprises (SMEs) Access to Finance in Selected East Asian Economies. ERIA Research Project Report 2010-14.

Watson, J. (2011). Networking: Gender differences and the association with firm performance. International Small Business Journal, 30(5), 536-558. https://doi.org/10.1177/0266242610384888

Wit, G. de, \& Kok, J. de. (2014). Do small businesses create more jobs? New evidence for Europe. Small Business Economics, 42(2), 283-295. https://doi.org/10.1007/s11187-013-9480-1

Wooldridge, J. M. (2010). Econometric Analysis of Cross Section and Panel Data (2nd edn): Cambridge, MA., London, MIT.

World Bank. (2015). Small and Medium Enterprises (SMEs) Finance. Retrieved from http://www.worldbank.org/en/topic/financialsector/brief/smes-finance.print

\section{Notes}

Note 1. Raosoft is a free software used to calculate the sample size in our survey.

Note 2. USD $1.00=$ VND 22000 at the time of the survey.

Note 3. Tests comparing SMEs that received a bank loan or that did not.

\section{Appendix}

Appendix 1. The definition of SMEs in Vietnam

\begin{tabular}{lll}
\hline Type of Firm & Number of Employees & Total Capital \\
\hline Micro & $1-10$ & \\
Small & $11-200$ & Maximum VND 20 billion (USD 900 000) \\
Medium & $201-300$ & VND 20 - 100 billion (USD 4.5 million) \\
\hline
\end{tabular}

Source: Decree No. 56 (2009). 
Appendix 2. Independent variables used in logistic regression analysis

\begin{tabular}{ll}
\hline Variables & Measurement \\
\hline $\begin{array}{l}\text { 1. Dependent Variable } \\
\text { Getting a bank loan }\end{array}$ & $1=$ had a bank loan; $0=$ did not have a bank loan \\
Bank loan ratio & Bank loan ratio = bank loan over total capital \\
2. Independent Variables & \\
Managerial competency & Education level \\
& Management experience \\
& Managerial skills \\
Business information & Business plan \\
Networking & Emotional trust \\
& Knowledge trust ${ }^{*}$ \\
& Approachability \\
& Personal sharing \\
& Service; trade; manufacturing \\
Firm industry & Micro; small; medium \\
Firm size & $1=$ urban area; $0=$ rural area \\
Firm location &
\end{tabular}

Appendix 3. Measuring Manager Skills, Emotional Trust, Knowledge Trust, Approachability of Bank Officers, and Personal Information Sharing

\section{Manager Skills}

Five items (D1.3.6, D1.3.7, D1.3.8, D1.3.9, D1.3.10) were extracted to measure the managers' skills. The scale of these five items had a Cronbach's alpha of .899. However, if the fourth item (D1.3.9 -risk taking) was dropped, the Cronbach's alpha increased to .902. Therefore, I decided to drop it and to use the other four items (D1.3.6, D1.3.7, D1.3.8, and D1.3.10) to measure the managers' skills.

\section{Emotional Trust}

There were five items (E.1.5, E.1.6, E.1.7, E.1.8, and E.1.9) extracted to measure emotional trust. The scale of these five items had a Cronbach's alpha of .843. However, if the first item (E1.5- You rely on the bank official(s) to find ways of meeting business's changing financial needs) was dropped, the Cronbach's alpha increased to .882 . Therefore, I decided to drop it and to use the other four items (E.1.6, E.1.7, E.1.8, E.1.9) to measure emotional trust.

\section{Knowledge Trust}

Four items (E.1.1, E.1.2, E.1.3, E.1.4) were extracted to measure knowledge trust. These four items had a Cronbach's alpha of .876. All these four items were kept to measure this factor.

\section{Approachability of Bank Officers}

There were three items (E.1.12, E.1.13, E.1.14) extracted to measure approachability. These three items had a Cronbach's alpha of .819. All three items, therefore, were kept to measure approachability of bank officers.

\section{Personal Information Sharing}

There were two items (E.1.10, E.1.11) extracted to measure personal information sharing. These two items had a Cronbach's alpha of .718. Therefore, all two items were retained for this measure.

Results of Factor Analysis

\begin{tabular}{|c|c|c|}
\hline & Description & $\begin{array}{c}\text { Cronbach's } \\
\text { Alpha if Item } \\
\text { Deleted }\end{array}$ \\
\hline & Manager Skills & \\
\hline D1.3.6 & Managerial skills & .883 \\
\hline D1.3.7 & Analytical skills & .867 \\
\hline D1.3.8 & Creativity & .866 \\
\hline D1.3.9 & Risk-taking & .902 \\
\hline D1.3.10 & Innovation & .863 \\
\hline
\end{tabular}


$\alpha=.899$

Emotional Trust

E1.5 You rely on the bank official(s) to find ways of meeting your business's changing financial needs

E1.6 You get to know the bank credit official(s) (background, personal life, habits, etc.)

E1.7 You attend the important events of their personal life (e.g., wedding or funeral of their family's member)

E1.8 When appropriate, you give this/these bank official(s) some gifts

E1.9 You get together with them on some holiday occasions

$\alpha=.843$

\section{Knowledge Trust}

E1.1 The bank official(s) is/are available to help in a crisis

E1.2 You trust the advice from your bank official(s)

E1.3 You are confident that the bank official(s) understand your business .844

E1.4 The bank official(s) often come forward with positive suggestions to help your business $\alpha=.876$

Approachability of bank officers

E1.12 You prefer to avoid contact with bank officials .786

E1.13 The bank official(s) is/are not interested in your business

E1.14 You feel intimidated when dealing with (a) bank official(s) $\alpha=.819$

E1.10 You share with this/these bank credit official(s) some of your own personal information (e.g., background, personal life)

E1.11 You feel free to share with this/these bank credit official(s) your ideas, feelings, hopes, or problems that may not directly relate to business $\alpha=.718$

Appendix 4. Correlation matrix

\begin{tabular}{|c|c|c|c|c|c|c|c|c|c|c|c|c|c|c|c|}
\hline & & Trade & Service & Plan & Age & Gender & Edu- & Mana_ex & Mana_sk & $\begin{array}{l}\text { Firm } \\
\text { Size } \\
\end{array}$ & Emot- & Know- & Appr- & Pers- & Location \\
\hline 1. & $\begin{array}{l}\text { Trade }(1=\mathrm{SME} \\
\text { focuses } \\
\text { trading) }\end{array}$ & 1 & & & & & & & & & & & & & \\
\hline 2. & $\begin{array}{l}\text { Service (1 = SME } \\
\text { focuses } \\
\text { service) }\end{array}$ & $-0.6260^{*}$ & 1 & & & & & & & & & & & & \\
\hline 3. & Plan (1 = yes) & 0.0581 & -0.0927 & 1 & & & & & & & & & & & \\
\hline 4. & Age (in years) & 0.0565 & -0.102 & 0.0316 & 1 & & & & & & & & & & \\
\hline 5. & Gender $(1=$ male $)$ & -0.0463 & -0.0300 & -0.0913 & -0.00670 & 1 & & & & & & & & & \\
\hline 6. & $\begin{array}{l}\text { Education level (1 } \\
=\text { having a } \\
\text { university degree) }\end{array}$ & -0.0815 & 0.00260 & -0.00510 & $-0.2016^{*}$ & -0.0292 & 1 & & & & & & & & \\
\hline 7. & $\begin{array}{l}\text { Manager } \\
\text { experience (in } \\
\text { years) }\end{array}$ & 0.0627 & $-0.1468^{*}$ & 0.0562 & $0.3767 *$ & -0.0850 & 0.0107 & 1 & & & & & & & \\
\hline 8. & Manager skills $\mathrm{s}^{\mathrm{a}}$ & -0.0229 & -0.0798 & -0.00590 & -0.0120 & 0.0506 & $0.1913^{*}$ & $0.1710^{*}$ & 1 & & & & & & \\
\hline 9. & $\begin{array}{l}\text { Firm size }(1= \\
\text { small firm })\end{array}$ & $-0.2142 *$ & -0.0626 & $0.1575^{*}$ & 0.105 & 0.118 & 0.0635 & 0.103 & $0.1754^{*}$ & 1 & & & & & \\
\hline 10. & Emotional trust ${ }^{b}$ & -0.0680 & -0.00610 & $0.1332^{*}$ & 0.00480 & 0.113 & 0.00760 & -0.00530 & 0.0415 & 0.0941 & 1 & & & & \\
\hline 11. & Knowledge trust ${ }^{\mathrm{b}}$ & 0.0753 & -0.107 & $0.2396^{*}$ & $0.1609^{*}$ & -0.00730 & 0.00830 & 0.0292 & 0.0699 & $0.1837^{*}$ & $0.3230^{*}$ & 1 & & & \\
\hline 12. & Approachability ${ }^{\mathrm{b}}$ & -0.0267 & 0.0263 & -0.0751 & $-0.1220^{*}$ & 0.0490 & 0.0107 & -0.00780 & 0.0901 & -0.0571 & $0.4515^{*}$ & $-0.1737^{*}$ & 1 & & \\
\hline 13. & Personal sharing ${ }^{\mathrm{b}}$ & 0.0228 & 0.0240 & 0.0963 & -0.0152 & 0.0688 & 0.00180 & 0.0239 & $0.1237^{*}$ & -0.00690 & $0.6364^{*}$ & $0.1940^{*}$ & $0.4596^{*}$ & 1 & \\
\hline 14. & $\begin{array}{l}\text { Location }(1= \\
\text { located in urban } \\
\text { area) }\end{array}$ & -0.0383 & 0.0733 & $-0.1866^{*}$ & -0.0803 & $-0.1341^{*}$ & $0.1899^{*}$ & -0.0318 & -0.0831 & 0.00410 & 0.0277 & 0.0843 & -0.0855 & -0.0969 & 1 \\
\hline
\end{tabular}

Note. ${ }^{*} \mathrm{p}<0.10, * * \mathrm{p}<0.05, * * * \mathrm{p}<0.01$. 


\section{Copyrights}

Copyright for this article is retained by the author(s), with first publication rights granted to the journal.

This is an open-access article distributed under the terms and conditions of the Creative Commons Attribution license (http://creativecommons.org/licenses/by/4.0/). 